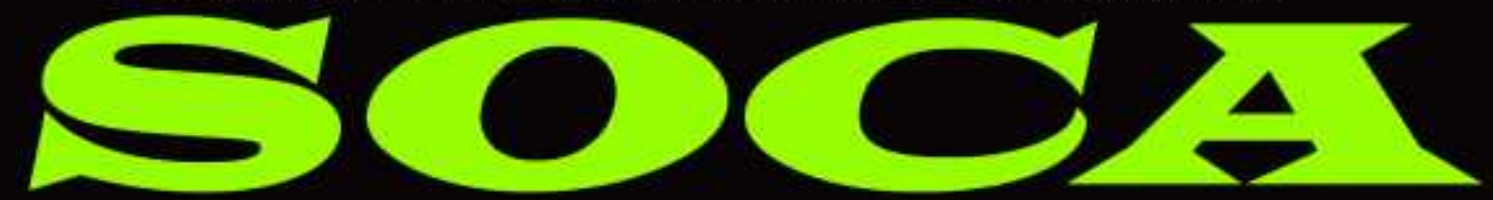

JOURNAL ON SOCIAL ECONOMICS OF AGRICULTURE

\title{
DETERMINAN KEPUASAN BELANJA KONSUMEN SAYUR ONLINE
}

\author{
James Sakoikoi dan Sony Heru Priyanto \\ Jurusan Agribisnis Fakultas Pertanian dan Bisnis Universitas Kristen Satya Wacana, Kota \\ Salatiga, Provinsi Jawa Tengah \\ Email: 522013028@student.uksw.edu dan sonecid@yahoo.com \\ HP: 081390523559 dan 085876699835
}

\begin{abstract}
ABSTRAK
Penerapan pemasaran secara online tidak hanya dilakukan pada produk industri, melainkan dilakukan untuk produk pertanian, salah satunya adalah sayuran segar organik. Penelitian ini bertujuan untuk mencari determinan kepuasan konsumen sayur (online) di antaranya adalah kepercayaan, penampilan produk (kemasan produk), kualitas produk, kualitas website, konten informasi, keanekaragaman produk, dan kemudahan transaksi. Penelitian telah dilaksanakan pada bulan April 2018 s/d Juni 2018, selama kurang lebih 60 hari dengan jumlah responden sebanyak 70 orang. Sedangkan tempat penelitian dilakukan di daerah Salatiga Jawa Tengah, Kabupaten Semarang. Penelitian ini merupakan jenis penelitian deskriptif kuantitatif dan metode yang digunakan dalam penelitian ini adalah metode survei. Teknik sampling yang digunakan dalam pengambilan sampel adalah non probality sampling dengan cara accidential sampling. Analisis data yang digunakan dalam penelitian ini adalah analisis deskriptif kuantitatif dengan analisis regresi linear sederhana. Adapun hasil yang diperoleh dari analisis yang dilakukan menunjukan bahwa variabel penampilan produk (kemasan produk), kualitas produk, kualitas website, konten informasi, keanekaragaman dan kemudahan bertransaksi sangat berpengaruh atau signifikan terhadap kepuasan, artinya konsumen merasa puas terhadap pembelian sayur secara online. Sedangakan variabel kepercayaan tidak berpengaruh terhadap kepuasan, dikarenakan ada faktor-faktor yang mempengaruhi kepuasan, yaitu hasil crosstab yang dimiliki nilainya sama besar tidak tinggi dan tidak rendah, sehingga untuk populasinya mengumpul atau tidak menyebar serta terdapat multikolinearitas yang cukup tinggi.
\end{abstract}

Kata kunci: kepuasan konsumen, toko online, tingkat kepercayaan 


\title{
DETERMINANTS OF COSTUMERS SATISFACTION IN VEGETABLES ONLINE SHOPPING
}

\begin{abstract}
The application of marketing online is not only conducted on industrial products, but rather made to agricultural products, one of which is organic fresh vegetables. This research aims to find determinant of consumer satisfaction vegetable (online) of which is trust, the appearance of the product (product packaging), the quality of the products, the quality of the website, the content of any information, product diversity, and the ease of the transaction. Research has been conducted in April 2018 s/d June 2018, for approximately 60 days by the number of respondents as many as 70 people. While doing research in the area of Salatiga in Central Java, Semarang. This research is quantitative descriptive research types and methods used in this research is a survey method. The sampling techniques used in sampling is a non probality sampling by means of accidential sampling. The analysis of the data used in this research is quantitative descriptive analysis with simple linear regression analysis. As for the results obtained from the analysis undertaken indicates that the variable is the appearance of the product (product packaging), the quality of the products, the quality of the website, the content of information, diversity and ease of transaction is very influential or significant against satisfaction, meaning consumers are satisfied against vegetable purchases online. While the variable trust has no effect against complacency, because there are factors that affect satisfaction, i.e. the results of the crosstab owned equally great value is not high and not low, so as to gather the population or do not spread and there is a fairly high multicollinearity.
\end{abstract}

Keyword: customer satisfaction, online store, trust level

\section{PENDAHULUAN}

Perilaku belanja online mengacu pada proses pembelian produk melalui internet. Maka pembelian secara online telah menjadi alternatif pembelian barang ataupun jasa. Penjualan secara online berkembang baik dari segi pelayanan, efektifitas, keamanan, dan juga popularitas. Pada zaman sekarang berbelanja secara online bukanlah hal yang asing. Konsumen tidak perlu mengeluarkan banyak tenaga saat berbelanja online, cukup dengan melihat website yang sesuai dengan tujuan yaitu toko online. Online shopping merupakan sebuah cara alternatif bagi masyarakat dalam melakukan kegiatan berbelanja, dengan menggunakan internet para

https://ojs.unud.ac.id/index.php/soca pelanggan dapat menghemat waktu, tenaga, dan tentunya lebih praktis bila dibandingkan dengan belanja secara tradisional.

Khususnya pada waktu belakangan ini sudah mulai marak bermunculan toko online yang menawarkan berbagai macam produk dan jasanya melalui media internet, oleh karena itu penelitian ini ditujukan untuk mengetahui mengenai faktor apa saja yang dapat mempengaruhi loyalitas dan kepuasan konsumen saat melakukan kegiatan berbelanja secara online. Online shopping itu sendiri mulai berkembang dan menjadi trend di masyarakat sejak tahun 2010. Perkembangan yang terjadi pada bisnis online shopping ini tergolong sangat cepat, karena sesuai dengan

https://doi.org/10.24843/SOCA.2019.v13.i02.p03 
kebutuhan masyarakat modern yang menginginkan segala sesuatunya serba capat dan praktis. Telah banyak terjadi perkembangan dalam bisnis online ini dari masa ke masa, salah satunya adalah website yang dapat memudahkan pelanggannya untuk melakukan transaksi melalui online payment (pembayaran secara online). Namun setiap sisi positif sudah pasti memiliki sisi negatif, begitu pula yang terjadi pada sistem online shopping, masih terdapat beberapa kekurangan dalam sistem ini, beberapa diantarnya adalah kepuasan pelanggan terhadap kepercayaan konsumen, penampilan produk (kemasan produk), kualitas produk, kualitas website, konten informasi, keanekaragaman dan kemudahan bertransaksi, yang ada pada sistem ini. Hal-hal tersebut dapat menyebabkan pelanggan menjadi enggan untuk melakukan transaksi perbelanjaan melalui online shopping. Factor-faktor pendorong kepuasan konsumen menurut Bachtiar (2011) adalah tingkat perasaan seseorang ketika menerima produk atau jasa yang ditawarkan serta membandingkan kinerja atas produk atau jasa yang diterima dengan harapan yang dimiliki.

Hasil penelitian sebelumnya oleh Atmawa dan Wahyuddin (2004) menunjukkan bahwa variabel independen yang terdiri dari kepercayaan, konten informasi, kualitas produk, kualitas website, keanekaragaman produk, berpengaruh positif dan signifikan terhadap kepuasan konsumen. Hasil uji koefisien regesi diperoleh bahwa semua variabel independen yang terdiri dari kepercayaan, konten informasi, kualitas produk, kualitas website, keanekaragaman produk, berpengaruh terhadap kepuasan konsumen. Dari hasil uji ekspektasi B atau Exp (B) diketahui bahwa kontribusi yang diberikan variabel kepercayaan terhadap kepuasan konsumen yang paling besar dibandingkan variabel keanekaragaman, konten informasi, kualitas produk, dan kualitas website. Hal ini ditunjukkan dari besarnya nilai $\operatorname{Exp}(B)=2,489$ yang paling besar dari nilai Exp (B) variabel yang lain. Hal ini juga dapat dilihat dari besarnya nilai koefisien beta variabel kepercayaan paling besar yaitu 0, 912. Hasil penelitian dimana setiap variabel eksogen memiliki pengaruh positif yang signifikan pada variabel endogennya. Dalam penelitain tersebut kemudahan transaksi berpengaruh positif terhadap minat beli secara online. Hasil penelitan Dharmayanti (2006) menunjukkan bahwa service performance memiliki pengaruh langsung yang kuat terhadap loyalitas nasabah dan service performance yang baik tidak selalu menghasilkan kepuasan nasabah tetapi hadirnya kepuasan nasabah sebagai variabel moderator, bukan sebagai variabel intervening, adalah tepat karena telah terbukti bahwa kepuasan nasabah mampu memoderate pengaruh service performance terhadap loyalitas nasabah. Hal ini ditunjukkan dengan nilai R2 dari model persamaan regresi moderator dimana peningkatan R2 semakin tinggi pada model ketiga yang memasukkan interaksi variabel service performance dan kepuasan nasabah sebagai moderating variable. Hasil penelitian Samuel dan Foedjiwati (2005) menunjukkan bahwa terdapat hubungan pengaruh positif yang signifikan antara kepuasan konsumen dengan kemasan produk/merk, hal ini menunjukkan bahwa penelitian ini 
mendukung teori tentang kemasan produk/merk. Berdasarkan latar belakang tersebut diatas maka peneliti bermaksud akan mengukur determinan kepuasan belanja konsumen sayur online, sebagaimana dilakukan penelitian terdahulu yang berjudul (Determinan Kepuasan Konsumen dalam pembelian Buah Segar Pada Toko Fress-E Di Kota Depok tahun 2004).

\section{METODE PENELITIAN}

\section{Jenis dan Metode Penelitian}

Penelitian ini dilakukan di kota Salatiga Kabupaten Semarang Jawa Tengah, tempat penelitian yang berlokasi di Salatiga. Penelitian telah dilaksanakan pada bulan April 2018 s/d Juni 2018, selama kurang lebih 60 hari. Dalam penelitian ini yang menjadi populasi adalah seluruh konsumen yang membeli sayur organik secara online di Salatiga. Sampel merupakan bagian dari jumlah dan karakteristik yang dimiliki oleh populasi. Sampel merupakan suatu subyek dari populasi dimana sampel ialah terdiri dari beberapa anggota populasi (Mamang dan Sopiah, 2010). Teknik sampling yang digunakan dalam pengambilan sampel adalah non probality sampling dengan cara accidential sampling. Sedangkan menurut Martono (2012) accidential sampling adalah teknik penentuan sampel berdasarkan kebetulan, dengan sayarat sampel yang diambil tersebut dapat dijadikan sumber data sesuai dengan karakteristik populasi. Jumlah sampel yang akan diambil dalam penelitian ini adalah sebanyak 70 responden konsumen. Dalam penelitian ini yang menjadi pertimbangan dalam pengambilan sampel adalah jumlah variabel independen yang digunakan sebanyak
7 dan jumlah transaksi maksimal 10 kali, sehingga ukuran sampel yang digunakan adalah $7 \times 10=70$. Dengan demikian jumlah sampel yang digunakan dalam penelitian ini adalah sebanyak 70 responden.

Penelitian ini merupakan jenis penelitian deskriptif kuantitatif. Penelitian deskriptif dimaksud untuk mengukur dengan cermat fenomena sosial tertentu, dalam penelitian ini terkait dengan fenomena determinan kepuasan konsumen terhadap suatu produk serta faktor yang mempengaruhinya (Kotler 2002:42). Metode yang digunakan dalam penelitian ini adalah metode survei dengan menggunkan instrument penelitian berupa kuisioner. Untuk memperoleh fakta dalam penelitian ini, informasi dikumpulkan melalui hasil wawancara konsumen yang melakukan pembelian secara online. Wawancara dilakukan berdasarkan daftar pertanyaan (kuisioner) yang telah disusun secara terstruktur oleh peneliti. (Effendi dan Tukiran, 2012).

Berdasarkan teknik pengumpulan data dalam penelitian ini menggunakan dua macam data, yaitu data primer dan data sekunder. Data primer adalah ada yang diperoleh secara langsung dari sumber atau objek penelitian. Menurut Mamang dan Sopiah (2010) data primer dapat berupa opini subjek baik secara individu maupun kelompok, hasil observasi peneliti terhadap suatu benda, kejadian ataupun kegiatan, serta hasil dari pengujian. Data primer ini yang digunakan dalam penelitian ini adalah hasil pengisian kuisioner oleh responden, yaitu konsumen (melakukan transaksi secara online). Data sekunder merupakan data yang diperoleh dari data yang dibutuhkan dalam mendukung penelitian. Umar 
(2011) dalam bukunya mengatakan bahwa data sekunder merupakan data primer yang telah diolah lebih lanjut dan disajikan baik oleh pihak pengumpul data primer maupun pihak lain misalnya dalam bentuk tabel-tabel atau diagram-diagram. Data sekunder yang digunakan dalam penelitian ini data internal perusahaan itu sendiri seperti sejarah perusahaan dan studi pustaka melalui jurnal, skripsi, literatur-literatur yang berkaitan dengan penelitian, serta informasi lain yang dapat diperoleh dengan media internet.

\section{Analisis Regresi Linier Sederhana}

Analisis regresi linear sederhana digunakan untuk mengetahui ada tidaknya pengaruh antara veriabel bebas dengan variabel terikat dengan perlakuan analisis per variabel. Variable bebas meliputi: Kepercayaan $\left(\mathrm{X}_{1}\right)$, Penampilan produk (kemasan produk) $\left(\mathrm{X}_{2}\right)$, Kualitas produk $\left(\mathrm{X}_{3}\right)$, Kualitas website $\left(\mathrm{X}_{4}\right)$, Konten Informasi (X), Keanekaragaman produk $\left(\mathrm{X}_{6}\right)$, dan Kemudahan transaksi, terhadap kepuasan konsumen online. Regresi sederhana didasarkan pada hubunngan fungsional ataupun kausal satu variabel indpeden dengan satu variabel dependen. Persamaan umum regresi linier sederhana adalah: $\mathrm{Y}=\mathrm{a}+\mathrm{bX}$
Dimana:

$\mathrm{Y}=$ Kepuasan konsumen

$\mathrm{a}=$ Intersep atau Konstanta

$\mathrm{b}=$ Angka koefisien regresi

Variablel-variabel independen

$\mathrm{X}_{1} \quad=$ Kepercayaan

$\mathrm{b}_{1} \quad=$ Koefisien Regresi Dari $\mathrm{X}_{1}$

$\mathrm{X}_{2} \quad=$ Penampilan produk (kemasan)

$\mathrm{b}_{2} \quad=$ Koefisien Regresi Dari $\mathrm{X}_{2}$

$\mathrm{X}_{3} \quad=$ Kualitas Produk

$\mathrm{b}_{3} \quad=$ Koefisien Regresi Dari $\mathrm{X}_{3}$

$\mathrm{X}_{4} \quad=$ Kualitas Website

\section{HASIL DAN PEMBAHASAN}

\section{Berdasarkan Karakteristik Responden}

Berdasarkan tabel 1 di bawah diketahui bahwa jenis kelamin dengan frekuensi tertinggi dalam penelitian ini yaitu sebanyak 64 orang atau 91,4\% dengan jenis kelamin perempuan. Sedangkan frekuensi terendah yaitu sebanyak 6 orang atau $8,6 \%$ dengan

$$
\begin{array}{ll}
\mathrm{b}_{4} & =\text { Koefisien Regresi Dari } \mathrm{X}_{4} \\
\mathrm{X}_{5} & =\text { Konten Informasi } \\
\mathrm{b}_{5} & =\text { Koefisien Regresi Dari } \mathrm{X}_{5} \\
\mathrm{X}_{6} & =\text { Keanekaragaman Produk } \\
\mathrm{b}_{6} & =\text { Koefisien Regresi Dari X } \\
\mathrm{X}_{7} & =\text { Kemudahan Transaksi } \\
\mathrm{b}_{7} & =\text { Koefisien Regresi Dari } \mathrm{X}_{7}
\end{array}
$$

jenis kelamin laki-laki. Dalam hal ini dimana responden yang ditemui oleh peneliti dan yang bersedia untuk diwawancarai yaitu perempuan dikarenakan perempuan lebih banyak melakukan pembelian produk secara online dibandingkan dengan laki-laki, salah satu produk yang mereka beli yaitu sayuran organik. 
Tabel 1. Karakteristik Responden Berdasarkan Jenis Kelamin

\begin{tabular}{ccc}
\hline Jenis kelamin & Frekuensi & Persentase (\%) \\
\hline Laki-Laki & 6 & 8.6 \\
Perempuan & 64 & 91.4 \\
Jumlah & 70 & 100.0
\end{tabular}

Sumber: Analisis Data Primer, 2018

Berdasarkan tabel 2 di bawah dapat diketahui dalam penelitian ini bahwa status perkawinan yang belum kawin paling tinggi yaitu sebanyak 57 orang atau $81,4 \%$. Sedangkan statur yang sudah kawin yang paling rendah adalah sebanyak 13 orang atau 18,6\%.
Dalam penelitian ini responden dengan status belum kawin lebih tinggi dibandingkan dengan yang berstatus sudah kawin. Yang belum kawin itu rata-rata masih sekolah dan masih usia sangat produktif.

Tabel 2 Karakteristik Responden Berdasarkan Status Perkawinan

\begin{tabular}{ccc}
\hline Kelompok & Frekuensi & Persentase (\%) \\
\hline Belum Kawin & 57 & 81.4 \\
Sudah Kawin & 13 & 18.6 \\
Jumlah & 70 & 100
\end{tabular}

Sumber: Analisis Data Primer, 2018

Berdasarkan tabel 3 dapat diketahui bahwa pendidikan responden terendah Sekolah Dasar (SD) sebanyak 3 orang atau 4,3\%, kemudian pada Sekolah Menengah Pertama (SMP) sebanyak 5 orang atau 7,1\%, kemudian Sekolah Menengah Atas/Kejuruan sebanyak 57 orang atau $81,4 \%$, kemudian (D3) sebanyak 1 orang atau $1,4 \%$, kemudian $\mathrm{S} 1$ atau tingkat pendidikan tertinggi sebanyak

Tabel 3 Karakteristik Responden Berdasarkan Pendidikan Terakhir

\begin{tabular}{ccc}
\hline Pendidikan Terakhir & Frekuensi & Persentase (\%) \\
\hline SD & 3 & 4.3 \\
SMP & 5 & 7.1 \\
SMA/SMK & 57 & 81.4 \\
D3 & 1 & 1.4 \\
S1 & 4 & 5.7 \\
\hline Jumlah & 70 & 100.0 \\
\hline
\end{tabular}

Sumber: Analisis Data Primer, 2018

4 orang atau $5,7 \%$. Dari data di bawah mayoritas pendidikan terakhir pengguna online shopping adalah Sekolah Menengah Atas/Kejuruan (SMA/SMK), karena peneliti mendapatkan responden rata-rata masih di bangku sekolah SMA/K, sehingga dapat disimpulkan bahwa pengguna onlineshop yang paling banyak yaitu anak SMA/K/. 
Berdasarkan tabel 4 dapat diketahui bahwa konsumen melakukan proses belanja online dengan menggunakan Facebook sebanyak 4 orang atau 5,7\%, kemudian konsumen yang menggunakan aplikasi Lazada sebanyak 6 orang atau 8,6\%, kemudian konsumen yang menggunkan aplikasi WhatsApp sebanyak 24 orang atau 34,3\%, kemudian konsumen yang menggunkan aplikasi Instagram sebanyak 5 orang atau $7,1 \%$, kemudian konsumen yang menggunakan aplikasi Bukalapak sebanyak 11 orang atau 15,7\%, kemudian konsumen yang menggunakan aplikasi Line sebanyak 4 orang atau 5,7\%, kemudian konsumen yang menggunakan aplikasi Tokopedia sebanyak 5 orang atau $7,1 \%$, kemudian konsumen yang menggunakan aplikasi Nyayur sebanyak 4 orang atau 5,7\%, dan konsumen yang menggunakan aplikasi Shopee sebanyak 7 orang atau $10 \%$. Responden yang paling banyak menggunakan aplikasi online untuk bertransaksi adalah aplikasi WhatsApp, dengan alasan karena aplikasi tersebut lebih sering dipake dalam dunia belanja online dari pada aplikasi lainnya. Di sisi lain juga produsen dalam menawarkan produk ke konsumen melalui website pasti akan melampirkan kontak person, salah satunya WhatsApp. Karena dikalangan konsumen saat ini lebih banyak menggunakan aplikasi WhatsApp, karena aplikasi tersebut sangat mudah diaplikasikan.

Tabel 4. Karakteristik Berdasarkan Jenis Aplikasi

\begin{tabular}{ccc}
\hline Jenis Aplikasi & Frequency & Percent (\%) \\
\hline Facebook & 4 & 5.7 \\
Lazada & 6 & 8.6 \\
WhatsApp & 24 & 34.3 \\
Instagram & 5 & 7.1 \\
Bukalapak & 11 & 15.7 \\
Line & 4 & 5.7 \\
Tokopedia & 5 & 7.1 \\
Nyayur & 4 & 5.7 \\
Shopee & 7 & 10.0 \\
\hline Jumlah & 70 & 100
\end{tabular}

Sumber: Analisis Data Primer, 2018

\section{Hasil Analisis Regresi Linear Sederhana}

Pada penelitian ini, analisis regresi sederhana dengan bantuan software SPSS versi 19 for windows dengan tujuan untuk membuktikan hipotesis mengenai pengaruh tingkat kepuasan konsumen. Hasil dari pengolahan data dengan program SPSS adalah sebagai berikut: 
Tabel 5. Hasil Analisis Regresi Sederhana

\begin{tabular}{|c|c|c|c|c|}
\hline $\begin{array}{c}\text { Variabel } \\
\text { Independen }\end{array}$ & Koefisien & T-hitung & Sig & Kesimpulan \\
\hline Intersep & 14,890 & 18,203 & 0,000 & \\
\hline Kepercayaan (X1) & $\begin{array}{l}-0,037 \mathrm{~ns} \\
\mathrm{R}=0,065 \\
\mathrm{R}^{2}=0,004 \\
\text { Adj } \mathrm{R}^{2}=- \\
\quad 0,010\end{array}$ & $-0,0534$ & 0,595 & Tidak Berpengaruh \\
\hline Intersep & 3,637 & 2,679 & 0,009 & \\
\hline $\begin{array}{l}\text { Penampilan/keasan } \\
\text { produk (X2) }\end{array}$ & $\begin{array}{l}0,747^{* *} \\
R=0,065 \\
R^{2}=0,004 \\
\text { Adj } R^{2}=-0,10\end{array}$ & 7,984 & 0,000 & Berpengaruh \\
\hline Intersep & 9,090 & 11,641 & 0,000 & \\
\hline $\begin{array}{l}\text { Kualitas Produk } \\
\text { (X3) }\end{array}$ & $\begin{array}{l}0,401^{* *} \\
R=0,643 \\
R^{2}=0,413 \\
\text { Adj } R^{2}=0,404\end{array}$ & 6,915 & 0,000 & Berpengaruh \\
\hline Intersep & 10,158 & 13,853 & 0,000 & \\
\hline $\begin{array}{l}\text { Kualitas Website } \\
\text { (X4) }\end{array}$ & $\begin{array}{l}0,329 * * \\
R=0,582 \\
R^{2}=0,339 \\
\text { Adj } R^{2}=0,330\end{array}$ & 5,909 & 0,000 & Berpengaruh \\
\hline Intersep & 9,397 & 10,988 & 0,000 & \\
\hline $\begin{array}{l}\text { Konten } \\
\text { (X5) }\end{array}$ & $\begin{array}{l}0,381 * * \\
R=0,585 \\
R^{2}=0,342 \\
\text { Adj } R^{2}=0,333\end{array}$ & 5,950 & 0,000 & Berpengaruh \\
\hline Intersep & 7,118 & 9,241 & 0,000 & \\
\hline $\begin{array}{l}\text { Keanekaragaman } \\
\text { Produk (X6) }\end{array}$ & $\begin{array}{l}0,524 * * \\
R=0,758 \\
R^{2}=0,574 \\
\text { Adj } R^{2}=0,568\end{array}$ & 9,570 & 0,000 & Berpengaruh \\
\hline Intersep & 9,547 & 12,282 & 0,000 & \\
\hline $\begin{array}{l}\text { Kemudahan } \\
\text { Transaksi (X7) }\end{array}$ & $\begin{array}{l}0,370 * * \\
R=0,611 \\
R^{2}=0,373 \\
\text { Adj } R^{2}=0,364 \\
\text { Fhitung = } \\
24,416 \\
D W=2,217\end{array}$ & 6,359 & 0,000 & Berpengaruh \\
\hline
\end{tabular}

Keterangan: *Nyata pada taraf kesalahan 5\%, Ns (NonSignificant) pada taraf kesalahan $5 \%$

Sumber: Analisis Data Primer, 2018 
Berdasarkan tabel di atas, maka persamaan regresi sederhana pengaruh $\mathrm{X} 1, \mathrm{X} 2, \mathrm{X} 3, \mathrm{X} 4, \mathrm{X} 5, \mathrm{X} 6$ dan $\mathrm{X} 7$ terhadap kepuasan konsumen sayur online sebagai berikut:

\section{Pengaruh Kepercayaan (X1) Terhadap Kepuasan Konsumen (Y)}

Variabel kepercayaan diwakili oleh tiga pertanyaan mengenai kepercayaan yakni: yakin terhadap (kehandalan) oleh instansi yang terkait, kemudian yakin terhadap kejujuran dalam pelayanannya, dan yakin atas hubungan yang terjalin dengan baik oleh pihak instansi terkait. Membangun kepercayaan dengan konsumen di toko online merupakan tantangan yang dihadapi oleh semua penyedia layanan toko online, terutama toko online yang baru beroperasi yang belum memiliki reputasi dan pengalaman dalam

$$
\begin{array}{ll}
\mathrm{Y}=14,890-0,037 & \mathrm{Y}=3,637+0,747 \\
\mathrm{Y}=9,090+0,401 & \mathrm{Y}=10,158+0,329 \\
\mathrm{Y}=9,397+0,381 & \mathrm{Y}=7,118+0,524 \\
\mathrm{Y}=9,547+0,370 &
\end{array}
$$

melakukan jual beli. Namun, toko online bisa melakukan beberapa usaha untuk meyakinkan konsumen supaya mereka percaya terhadap jasa yang disediakan oleh produsen. Dari hasil SPSS yang telah dilakukan, bahwa variabel kepercayaan tidak berpengaruh terhadap variabel kepuasan konsumen. Dalam hal ini ada faktor-faktor yang mempengaruhinya, di antaranya adalah: dari hasil crosstab yang dimiliki nilainya sama besar tidak tinggi dan tidak rendah, sehingga untuk populasinya mengumpul atau

\begin{tabular}{|c|c|c|c|c|c|}
\hline \multirow{2}{*}{$\mathrm{X}_{1}$} & & \multirow[t]{2}{*}{$\mathrm{Y}$} & \multicolumn{2}{|c|}{ Kepuasan Konsumen } & \multirow{2}{*}{ Total } \\
\hline & & & Setuju & Sangat Setuju & \\
\hline \multirow{6}{*}{ Kepercayaan } & & Count & 2 & 22 & 24 \\
\hline & Netral & $\begin{array}{l}\text { Expected } \\
\text { Count }\end{array}$ & 5.8 & 18.2 & 24.0 \\
\hline & & Count & 15 & 11 & 26 \\
\hline & Setuju & $\begin{array}{l}\text { Expected } \\
\text { Count }\end{array}$ & 6.3 & 19.7 & 26.0 \\
\hline & Sonont & Count & 0 & 20 & 20 \\
\hline & Setuju & $\begin{array}{l}\text { Expected } \\
\text { Count }\end{array}$ & 4.9 & 15.1 & 20.0 \\
\hline \multirow{2}{*}{\multicolumn{2}{|c|}{ Total }} & Count & 17 & 53 & 70 \\
\hline & & $\begin{array}{l}\text { Expected } \\
\text { Count }\end{array}$ & 17.0 & 53.0 & 70.0 \\
\hline
\end{tabular}
tidak menyebar serta terdapat multikolinearitas yang cukup tinggi.

Tabel 6. Distribusi Nilai Kepuasan Konsumen Menurut Variabel Kepercayaan

Sumber: Analisa Data Primer, 2018

\section{Pengaruh Penampilan (Kemasan Produk) (X2) Terhadap Kepuasan (Y)}

Variabel penampilan (kemasan produk) diwakili oleh tiga pertanyaan mengenai penampilan (kemasan produk) yakni: tertarik dengan pengemasan produk agar produk terlindung dari cuaca, kemudian tertarik dengan tujuan pengemasan 
produk agar produk terlindungi dari benturan-benturan benda lain, serta ketertarikan dengan pengemasan produk yang ditawarkan oleh pihak terkait dalam penjualan secara online. Melalui uji validitas ketiga pertanyaan mengenai penampilan (kemasan produk) memiliki nilai Corected Item Total Correlation $>0,231$ sehingga dinyatakan valid. Melalui uji reliabilitas variabel penampilan (kemasan produk) mendapatkan nilai Cronbach Alpha sebesar 0,658 sehigga dinyatakan reliabel.

Secara statistik penampilan (kemasan produk) (X2) berpengaruh signifikan terhadap kepuasan (Y) dengan nilai $t_{\text {hitung }}(7,984)>t_{\text {tabel }}$ (1.66660). Hal ini bahwa penampilan (kemasan produk) berpengaruh signifikan. Semakin tinggi nilai penampilan (kemasan produk) akan semakin baik begitupun sebaliknya.
Penampilan suatu produk sangat berpengaruh terhadap kepuasan seseorang atau kelompok tertentu, karana hal itu akan dinilai oleh pihak pembeli apakah penampilan atau kemasan produk dapat dipastikan akan terlindung dari cuaca, apakah kemasan produk akan terlindung dari benturan-benturan terhadap benda lainnya atau hanya menang dengan penampilannya saja, hal ini sangat menentukan konsumen merasa puas terhadap produk yang dibeli atau dikecewakan. Penampilan produk/kemasan produk atau packaging, diartikan secara umum adalah bagian terluar yang membungkus suatu produk dengan tujuan untuk melindungi produk dari cuaca, guncangan dan benturanbenturan, terhadap benda lain $(J$. Fernando, TD. Desyana, and $A$. Christian, 2014).

Tabe1 7. Distribusi Nilai Kepuasan Konsumen Menurut Nilai Variabel Penampilan (kemasan produk)

\begin{tabular}{|c|c|c|c|c|c|}
\hline \multirow{2}{*}{$\mathrm{x} 2$} & & & \multicolumn{2}{|c|}{ Kepuasan Konsumen } & \multirow[b]{2}{*}{ Total } \\
\hline & & Y & Setuju & $\begin{array}{l}\text { Sangat } \\
\text { Setuju }\end{array}$ & \\
\hline \multirow{4}{*}{$\begin{array}{c}\text { Penampilan (kemasan } \\
\text { produk) }\end{array}$} & & Count & 4 & 2 & 6 \\
\hline & Setuju & $\begin{array}{l}\text { Expected } \\
\text { Count }\end{array}$ & .5 & 5.5 & 6.0 \\
\hline & Conort & Count & 2 & 62 & 64 \\
\hline & Setuju & $\begin{array}{l}\text { Expected } \\
\text { Count }\end{array}$ & 5.5 & 58.5 & 64.0 \\
\hline \multirow[b]{2}{*}{ Total } & & Count & 6 & 64 & 70 \\
\hline & & $\begin{array}{l}\text { Expected } \\
\text { Count }\end{array}$ & 6.0 & 64.0 & 70.0 \\
\hline
\end{tabular}

Sumber: Analisis Data Primer, 2018

\section{Pengaruh Kualitas Produk (X3) terhadap Kepuasan (Y)}

Variabel kualitas produk diwakili oleh empat nilai pertanyaan mengenai kualitas produk di antaranya yakni: kepuasan terhadap produk yang ditawarkan, kemudian kepuasan terhadap daya tahan produk yang ditawarkan, kemudian kepuasan terhadap ketepatan produk karena sesuai dengan harapan, serta kepuasan terhadap tindakan cepat tanggap operasi dan perbaikan produk yang rusak. Melalui uji validitas ke 
empat pertanyaan mengenai kualitas produk memiliki nilai Coreected Item Total Correlation $>0,231$ sehingga dinyatakan valid. Melalui uji realibilitas variabel kualitas produk mendapatkan Cronbach Alpha sebesar 0,633 sehigga dinyatakan reliabel. Kualitas produk sangat berperan penting terhadap kepuasan konsumen, karena kualitas produk meningkatkn daya beli terhadap produk yang ditawarkan. Secara statistik kualitas produk (X3) berpengaruh signifikan terhadap kepuasan $(\mathrm{Y})$ dengan nilai nilai thitung $(6,915)>t_{\text {tabel }}(1.66660)$. hal ini berarti bahwa kualitas produk berpengaruh signifikan. Hal ini sesuai dengan pernyataan Kotler (2009:144) yaitu Kualitas produk, kepuasan pelanggan, adalah hal erat. Semakin tinggi tingkat kualitas, semakin tinggi tingkat kepuasan yang dihasilkan. Hasil penelitian deskriptif ini adalah variabel kualitas produk terhadap pengaruh variabel kepuasan konsumen.

Tabel 8. Distribusi Nilai Kepuasan Konsumen Menurut Nilai Variabel Kualitas

Produk

\begin{tabular}{|c|c|c|c|c|c|c|}
\hline \multirow{2}{*}{$\mathrm{x} 3$} & & \multirow[b]{2}{*}{$\mathrm{Y}$} & \multicolumn{3}{|c|}{ Kepuasan Konsumen } & \multirow[b]{2}{*}{ Total } \\
\hline & & & $\begin{array}{l}\text { Tidak } \\
\text { Setuju }\end{array}$ & Netral & Setuju & \\
\hline \multirow{4}{*}{ Kualitas Produk } & & Count & 0 & 6 & 0 & 6 \\
\hline & Setuju & $\begin{array}{l}\text { Expected } \\
\text { Count }\end{array}$ & .3 & 3.0 & 2.7 & 6.0 \\
\hline & & Count & 3 & 29 & 32 & 64 \\
\hline & $\begin{array}{l}\text { Sangat } \\
\text { Setuju }\end{array}$ & $\begin{array}{l}\text { Expected } \\
\text { Count }\end{array}$ & 2.7 & 32.0 & 29.3 & 64.0 \\
\hline \multirow[b]{2}{*}{ Total } & & Count & 3 & 35 & 32 & 70 \\
\hline & & $\begin{array}{l}\text { Expected } \\
\text { Count }\end{array}$ & 3.0 & 35.0 & 32.0 & 70.0 \\
\hline
\end{tabular}

Sumber: Analisis Data Primer, 2018

\section{Pengaruh Kualitas Website (X4) terhadap Kepuasan (Y)}

Variabel kualitas webite diwakili oleh empat pertanyaan mengenai kualitas website di antaranya adalah yakni: kepuasan terhadap informasi yang disajikan melalui website, kemudian kepuasan terhadap situs yang sangat mudah diakses, kemudian kepuasan terhadap keamanan situs website, serta kepuasan terhadap kenyamanan dalam menggunakan website. Melalui uji validitas kelima pertanyaan mengenai kualitas website memiliki Corerected Item - Total Correlation > 0,231 sehingga dinyatakan valid.
Melalui uji realibilitas variabel kualitas website mendapatkan nilai Cronbach Alpha sebesar 0,640 sehingga dinyatakan reliabel.

$$
\text { Kualitas website sangat }
$$

berperan penting dalam menentukan tingkat kepuasan konsumen. Karena kualitas website dapat meningkatkan daya beli konsumen terhadap produk yang ditawarkan secara online. Secara statistik kualitas website (X4) berpengaruh signifikan terhadap kepuasan $(\mathrm{Y})$ dengan nilai $\mathrm{t}_{\text {hitung }}(5,909)$ $>t_{\text {tabel }}(1.66660)$. Hal ini berarti bahwa kualitas website berpengaruh signifikan. Koefisien yang bernilai positif berarti semakin tinggi kualitas 
website maka kepuasan konsumen semakin baik, begitu juga dengan sebaliknya. Menurut (Hyejeong dan Niehm, 2009:222) mengungkapkan bahwa kualitas website merupakan

Tabel 9. Distribusi Nilai Kepuasan Konsumen Menurut Nilai Variabel Kualitas

\begin{tabular}{|c|c|c|c|c|c|}
\hline \multirow{2}{*}{$\mathrm{X}_{4}$} & & \multirow[t]{2}{*}{$\mathrm{Y}$} & \multicolumn{2}{|c|}{ Kepuasan Konsumen } & \multirow[b]{2}{*}{ Total } \\
\hline & & & Setuju & $\begin{array}{l}\text { Sangat } \\
\text { Setuju }\end{array}$ & \\
\hline \multirow{3}{*}{ Kualitas Website } & $\begin{array}{l}\text { Tidak } \\
\text { Setuju }\end{array}$ & $\begin{array}{l}\text { Count } \\
\text { Expected } \\
\text { Count }\end{array}$ & $\begin{array}{l}0 \\
.2\end{array}$ & $\begin{array}{c}2 \\
1.8\end{array}$ & $\begin{array}{c}2 \\
2.0\end{array}$ \\
\hline & Netral & $\begin{array}{l}\text { Count } \\
\text { Expected } \\
\text { Count }\end{array}$ & $\begin{array}{c}6 \\
4.3\end{array}$ & $\begin{array}{c}44 \\
45.7\end{array}$ & $\begin{array}{c}50 \\
50.0\end{array}$ \\
\hline & Setuju & $\begin{array}{l}\text { Count } \\
\text { Expected } \\
\text { Count }\end{array}$ & $\begin{array}{c}0 \\
1.5\end{array}$ & $\begin{array}{c}18 \\
16.5\end{array}$ & $\begin{array}{c}18 \\
18.0\end{array}$ \\
\hline \multicolumn{2}{|l|}{ Total } & $\begin{array}{l}\text { Count } \\
\text { Expected } \\
\text { Count }\end{array}$ & $\begin{array}{c}6 \\
6.0\end{array}$ & $\begin{array}{c}64 \\
64.0\end{array}$ & $\begin{array}{c}70 \\
70.0\end{array}$ \\
\hline
\end{tabular}

Sumber: Analisa Data Primer, 2018

\section{Pengaruh Konten Informasi (X5) terhadap Kepuasan (Y)}

Variabel konten informasi diwakili oleh empat pertanyaan mengenai konten informasi yang meliputi: kepuasan terhadap konten informasi yang relevan dan sangat membantu, kemudian kepuasan terhadap informasi yang disajikan selalu baru dan terupdate serta kepuasan terhadap konten informasi yang disajikan website untuk suatu produk telah menggambarkan produk yang diharapakan. Melalui uji validitas keempat pertanyaan mengenai konten informasi memiliki nilai Corerected Item - Total Correlation > 0,231 sehingga dinyatakan valid. Melalui uji realibilitas mendapatkan nilai Cronbach Alpha sebesar 0,629 sehingga dinyatakan reliabel. Secara statistik konten informasi (X5) berpengaruh signifikan terhadap kesesuaian terhadap persyaratan yang meliputi: Informasi, keamanan, kemudahan, kenyamanan, serta kualitas pelayanan.

\section{Website}


pembelian produk yang diinginkan dan sesuai dengan harapannya. Jika informasi yang disajikan melalui website tidak sesuai dengan harapan konsumen, makan akan sangat berpengaruh besar terhadap kepuasan dan bahkan akan terjadi kekecewaan yang cukup besar.

Tabel 10. Distribusi Nilai Kepuasan Konsumen Menurut Nilai Variabel Konten Informasi

\begin{tabular}{|c|c|c|c|c|c|}
\hline \multirow{2}{*}{$\mathrm{X}_{5}$} & & \multirow[t]{2}{*}{$\mathrm{Y}$} & \multicolumn{2}{|c|}{ Kepuasan Konsumen } & \multirow[b]{2}{*}{ Total } \\
\hline & & & Setuju & $\begin{array}{l}\text { Sangat } \\
\text { Setuju }\end{array}$ & \\
\hline \multirow{6}{*}{$\begin{array}{l}\text { Konten } \\
\text { Informasi }\end{array}$} & \multirow[b]{2}{*}{$\begin{array}{c}\text { Tidak } \\
\text { Setuju }\end{array}$} & Count & 1 & 3 & 4 \\
\hline & & $\begin{array}{l}\text { Expected } \\
\text { Count }\end{array}$ & .9 & 3.1 & 4.0 \\
\hline & \multirow[b]{2}{*}{ Netral } & Count & 14 & 40 & 54 \\
\hline & & $\begin{array}{l}\text { Expected } \\
\text { Count }\end{array}$ & 11.6 & 42.4 & 54.0 \\
\hline & \multirow[b]{2}{*}{ Setuju } & Count & 0 & 12 & 12 \\
\hline & & $\begin{array}{l}\text { Expected } \\
\text { Count }\end{array}$ & 2.6 & 9.4 & 12.0 \\
\hline \multirow{2}{*}{\multicolumn{2}{|c|}{ Total }} & Count & 15 & 55 & 70 \\
\hline & & $\begin{array}{l}\text { Expected } \\
\text { Count }\end{array}$ & 15.0 & 55.0 & 70.0 \\
\hline
\end{tabular}

Sumber: Analisis Data Primer, 2018

\section{Pengaruh Keanekaragaman (X6) terhadap Kepuasan (Y)}

Variabel keanekaragaman diwakili tiga pertanyaan mengenai keanekaragaman di antaranya adalah kepuasan terhadap jumlah produk yang ditawarkan, kemudian kepuasan terhadap jenis produk yang begitu variatif serta kepuasan terhadap kelengkapan produk yang ditawarkan. Melalui uji validitas ketiga pertanyaan mengenai pengaruh keanekaragaman memiliki nilai Corerected Item - Total Correlation > 0,231 sehingga dinyatakan valid. Melalui uji realibilitas mendapatkan nilai Cronbach Alpha sebesar 0,740 sehingga dinyatakan reliabel.

Secara

statistik keanekaragaman (X6) berpengaruh signifikan terhadap kepuasan (Y) dengan nilai thitung $(9,570)>t_{\text {tabel }}$ (1.66660). Hal ini bahwa keanekaragaman berpengaruh signifikan. Koefisien dengan nilai positif berarti semakin tinggi nilai keanekaragaman maka tingkat kepuasan semakin baik, begitu juga sebaliknya. Keanekaragaman produk merupakan kondisi yang tercipta dari ketersediaan barang dalam jumlah dan jenis yang sangat variatif sehingga menimbulkan banyaknya pilihan dalam proses belanja konsumen (Asep, 2005:9). Keanekaragaman suatu produk berperan penting dalam menarik perhatian konsumen untuk membeli produk yang ditawarkan. Jika produk yang ditawarkan jenisnya homogen, maka konsumen merasa bosan karena tidak ada warna atau variasi dalam menawarkan produk untuk dijual, dalam hal ini produk yang ditawarkan sangatlah bervariatif sehingga konsumen merasa senang dan ingin mendapatkan produk yang diharapkannya. 
Tabel 11. Distribusi Nilai Kepuasan Konsumen Menurut Nilai Variabel Keanekaragaman

\begin{tabular}{|c|c|c|c|c|c|}
\hline \multirow{2}{*}{\multicolumn{2}{|c|}{$\mathrm{X}_{6} \mathrm{Y}$}} & & \multicolumn{2}{|c|}{ Kepuasan Konsumen } & \multirow[b]{2}{*}{ Total } \\
\hline & & & Setuju & $\begin{array}{l}\text { Sangat } \\
\text { Setuju }\end{array}$ & \\
\hline \multirow{6}{*}{ Keanekaragaman } & \multirow[b]{2}{*}{ Netral } & Count & 0 & 1 & 1 \\
\hline & & $\begin{array}{l}\text { Expected } \\
\text { Count }\end{array}$ & .1 & .9 & 1.0 \\
\hline & \multirow[b]{2}{*}{ Setuju } & Count & 5 & 11 & 16 \\
\hline & & $\begin{array}{l}\text { Expected } \\
\text { Count }\end{array}$ & 1.4 & 14.6 & 16.0 \\
\hline & \multirow[b]{2}{*}{$\begin{array}{l}\text { Sangat } \\
\text { Setuju }\end{array}$} & Count & 1 & 52 & 53 \\
\hline & & $\begin{array}{l}\text { Expected } \\
\text { Count }\end{array}$ & 4.5 & 48.5 & 53.0 \\
\hline \multirow[b]{2}{*}{ Total } & & Count & 6 & 64 & 70 \\
\hline & & $\begin{array}{l}\text { Expected } \\
\text { Count }\end{array}$ & 6.0 & 64.0 & 70.0 \\
\hline
\end{tabular}

Sumber: Analisis Data Primer, 2018

\section{Pengaruh Kemudahan Transaksi (X7) terhadap Kepuasan (Y)}

Variabel kemudahan transaksi diwakili dengan empat pertanyaan mengenai kemudahan transaksi yang meliputi; kepuasan terhadap transaksi secara online, kemudian kepuasan terhadap keamanan dalam melakukan transaksi secara online, serta kepuasan terhadap transaksi secara online. Melalui uji validitas keempat pertanyaan tentang kemudahan transaksi memiliki nilai Corerected Item - Total Correlation > 0,231 sehingga dinyatakan valid. Melalui uji realibilitas mendapatkan nilai Cronbach Alpha sebesar 0,637 sehingga dinyatakan reliabel.

Secara statistik kemudahan transaksi (X7) berpengaruh signifikan terhadap kepuasan $(\mathrm{Y})$ dengan nilai $t_{\text {hitung }}(6,359)>t_{\text {tabel }}(1.66660)$. Hal ini berarti bahwa kemudahan transaksi

$$
\text { berpengaruh signifikan. }
$$

Koefisien semakin bernilai positif berarti semakin tinggi nilai kemudahan transaksi maka tingkat kepuasan akan baik, begitu juga dengan sebaliknya. Proses kemudahan ini terkait dengan bagaimana operasional bertransaksi secara online. Biasanya calon pembeli akan mengalami kesulitan pada saat pertama kali bertransaksi online, dan cenderung mengurungkan niatnya karena faktor keamanan serta tidak tahu cara bertransaksi online (F.D. Davis, 1989). Kemudahan bertransaksi secara online akan sangat berpengaruh terhadap kepuasan seseorang atau kelompok tertentu. Jika dalam bertransaksi secara online keamanan, kenyamanan, kemudahan, serta durasi, tidak dapat dijamin, maka konsumen akan merasa tidak puas bahkan akan timbul kekecewaan dan mungkin tidak akan mempercayai pihak yang konsumen tuju. 
Tabel 12. Distribusi Nilai Kepuasan Konsumen Menurut Nilai Variabel Kemudahan Transaksi

\begin{tabular}{|c|c|c|c|c|}
\hline & & \multicolumn{2}{|c|}{ Kepuasan Konsumen } & \multirow[b]{2}{*}{ Total } \\
\hline & & Setuju & $\begin{array}{l}\text { Sangat } \\
\text { Setuju }\end{array}$ & \\
\hline \multirow{4}{*}{$\begin{array}{l}\text { Kemudahan } \\
\text { Transaksi }\end{array}$} & Count & 6 & 40 & 46 \\
\hline & $\begin{array}{c}\text { Netral Expected } \\
\text { Count }\end{array}$ & 3.9 & 42.1 & 46.0 \\
\hline & Count & 0 & 24 & 24 \\
\hline & $\begin{array}{c}\text { Setuju Expected } \\
\text { Count }\end{array}$ & 2.1 & 21.9 & 24.0 \\
\hline \multirow[b]{2}{*}{ Total } & Count & 6 & 64 & 70 \\
\hline & $\begin{array}{l}\text { Expected } \\
\text { Count }\end{array}$ & 6.0 & 64.0 & 70.0 \\
\hline
\end{tabular}

Sumber: Analisis Data Primer, 2018

\section{KESIMPULAN}

Berdasarkan hasil penelitian dan pembahasan pada bab sebelumnya, maka dapat disimpulkan sebagai berikut: Variablel-variabel yang berpengaruh signifikan dan variabel yang tidak berpengaruh signifikan untuk determinan tingkat kepuasan konsumen.

1. Variabel Penampilan (kemasan produk), Kualitas Produk, Kualitas Website, Konten Informasi, Keanekaragaman, serta Kemudahan Transaksi sangat berpengaruh positif terhadap variabel Kepuasan.

2. Sedangakan Variabel Kepercayaan dinyatakan tidak berpengaruh terhadap Kepuasan Konsumen Sayur Online, dikarenakan ada faktor-faktor yang mempengaruhi kepuasan konsumen. Faktor tersebut di antaranya adalah adanya hasil crosstab yang dimiliki nilainya sama besar tidak tinggi dan tidak rendah, sehingga untuk

\section{DAFTAR PUSTAKA}

Brilliant, M. A. dan Achyar, A. (2013). The Impact of Satisfaction and populasinya mengumpul atau tidak menyebar serta terdapat multikolinearitas yang cukup tinggi.

\section{SARAN}

Berdasarkan pembahasan dan kesimpulan dapat dirumuskan saran atau rekomendasi sebagai berikut:

1. Diharapkan pihak yang menjalankan atau mengelola aplikasi online shopping terkhususnya untuk penjualan sayur mayur perlu memperhatikan penampilan (kemasan produk), kualitas produk, kualitas website, konten informasi, keanekaragaman, serta kemudahan transaksi karena telah memberikan pengaruh yang positif terhadap kepuasan konsumen.

2. Perlu dilakukan penelitian lebih lanjut mengenai aspek determinan yang mempengaruhi kepuasan konsumen terhadap pembelian sayur secara online.

Trust on Loyalty of E Commerce Customers. Asean Marketing Journal.5(1) 51-58 
Levin, I., P. dan Gaeth, G. J. (1988). How Consumers Are Affected by the Framing of Attribute Information Before and After Consuming the Product. Journal of Consumer Research. 15, 374378.

Ribbink, Dina, Allard C. R. van Riel Veronica Liljander, dan Sandra Streukens. (2004) Comfort Your Online Customer: Quality, Trust, and Loyalty on The Internet, Managing Service Quality Journal, Vol. 14: 446 - 456.

Assael, H. (1998). Customer Behavior and Marketing Action. Ohio: SouthWestern College Publishing.

Shohibullana, I. H. (2014). Kontrol Diri Dan Perilaku Konsumtif Pada Siswa SMA (Ditinjau dari lokasi sekolah). Jurnal Online Psikologi.

N. Zeane, "Dampak Kehadiran Internet," Dampak Kehadiran Internet, (2009). [Online]. Available: $\quad$ http://zeampr.com/2009/11/dampakkehadiran-internetdalam.html.

Risnita. (2012). Pengembangan Skala Model Likert. Edu-Bio, 3, pp.8699.

Rofiq, Ainur. (2007). Pengaruh Dimensi Kepercayaan (Trust) Terhadap Partisipasi Pelanggan ECommerce (Studi Pada Pelanggan E-Commerce di Indonesia). Universitas Brawijaya.

Sidharta, Iwan \& Suzanto, B. (2015). Pengaruh Kepuasan Transaksi Online Shopping Dan Kepercayaan Konsumen
Terhadap Sikap Serta Perilaku Konsumen Pada ECommerce. STMIK Mardira Indonesia, Bandung.

Siregar, S. (2014). Statisti Parametrik untuk Penelitian Kuantitatif Dilengkapi dengan Perhitungan Manual dan Aplikasi SPSS Versi 17. Jakarta; Bumi Aksara.

Sugiyono. (2008). Statistika untuk Penelitian. Bandung: Alfabeta.Suki, Norazah. (2011). A structural modelo

Sumartono. (2002). Terperangkap Dalam Iklan. Bandung: Alfabeta.

David, 1. Loudo dan Albert J. Della Bitta. $\quad 1998 . \quad$ Consumer Behavior: Third Edition, New York. Mc Graw Hill Book Company, 1998.

Engel, James. F. Roger D. Blackwell dan Paul W. Miniard. (2003). Consumer Behavior. 11th Edition. The Dryden Press, Orlando.

Purwanto, Erwan Agus, Dyah R. Sulistyastuti. .2011. Metode Penelitian Kuantitatif. Yogyakarta: Gava Media.

Risnita. (2012). Pengembangan Skala Model Likert. Edu-Bio, 3, pp.8699.

Saragih, B. (2010). Agribisnis Paradigma Baru Pembangunan Ekonomi Berbasis Pertanian. IPB Press.Bogor

Supranto, J. (2006). Pengukuran Tingkat Kepuasan Pelanggan: Untuk Menaikkan Pangsa Pasar. Rineka Cipta.Jakarta 
BPS. (2015). Perkembangan Beberapa Agregat Pendapatan dan Pendapatan per Kapita Atas Dasar Harga Berlaku Tahun 2010-2014. Badan Pusat Statistik. Jakarta

N. M. S. Anggraeni and N. N. K. Yasa, "E-Service Quality terhadap Kepuasan dan Loyalitas Pelanggan dalam Penggunaan Internet Banking," vol. 16, no. 2, pp. 293-306, (2012)
J. Fernando, T. D. Desyana, and A. Christian, "Pengaruh loyalitas Pelanggan Terhadap Berbelanja Secara Online," Bina Nusant., (2014).

F. D. Davis, "Perceived usefulness, perceived ease of use, and user acceptance of information technology," Soc. Inf. Manag. Manag. Inf. Syst. Res. Cent. Univ. Minn., pp. 319-340, (1989). 